(3) E.Raub et. al., Metalloberflache 12, 161, 193 (1956)

(6) 加瀬，本誌，10，159（1959）

E.Raub et. al., Metalloberflache 13, 308 (1959)

(5) 加瀬5, 本誌, 9, 83 (1958)

(7) 加瀬, 本誌, 11, 259 (1960)

(8) R.Piontelli et. al., Trans. Inst. Met. Finishing 34, 293 (1957)

\title{
脱水リン酸一有機試薬系混合浴による鋼の化学研摩
}

\section{佐治孝* \\ Chemical Dip Polishing of Steel with Dehydrated Phosphoric Acid Containing Some Organic Reagents}

Takashi SAJI*

Chemical dip polishing action in the newly presented bath of dehydrated phosphoric acid (DPA) added with some organic solvents were investigated.

Appearances (smoothness, pitting and colouring) of the metal surface polished chemically in the above mentioned bath were observed, and the corrosion loss of the polished was also measured, taking the experimental conditions, such as bath composion, temperature and dipping duration, into consideration.

(1) Brightening action for steel was obtained by using the baths composed of 10 parts of DPA (concenterated up to $\mathrm{P}_{2} \mathrm{O}_{5} 78 \%$ ) and $1 \sim 5$ parts of such organic ingredients as alcohol, ether, keton,organic acid anhydride and their derivatives.

(2) It was found that these baths had the following characteristics compared with the conventional one which contains inorganic reagents besides DPA:

a) Smoothing action was more effective for steel,

b) The lower optimum temperature was found between 60 and $100^{\circ} \mathrm{C}$,

c) Corrosive behavior of steel was so small that the corrosion loss of the material immersed in this bath was reduceded to approximatly one half of that treated in the conventional bath.

(3) Some Organic compounds added to DPA seem to contribute to strengthen the activitiy for steel and to improve the ability of making flexible, porous film available for smoothing action of the bath.

\section{1. 緒言}

すでに筆者らは正りン酸を加熱脱水して得られる $\mathrm{P}_{2} \mathrm{O}_{5}$ $75 \%$ 付近の脱水リン酸 (以下 DPA とよぶ) の単独浴, あるいはこれに $\mathrm{H}_{2} \mathrm{SO}_{4}, \mathrm{CrO}_{3}$ のような無機鉱酸類を配 合した混合浴が鉄鋼の化学研摩浴として利用されること を述べだ。しかしこの種の研摩浴はその研摩の最適温 度範囲が 150 200 C にあり, 比較的高い温度のもとで 研摩操作を行なら必要がある。しかるに最近この DPA にある種の有機試薬を配合した浴が，鉄鋼に対し $100^{\circ} \mathrm{C}$ 以下の低温度域においてもすぐれた化学研摩能を発揮す る事実が見出され，この種の DPA-有機試薬混合系浴は 鉄鋼用の低温化学研摩浴として利用することも可能と考 えられるに至ったので，その化学研摩作用の概要につい て報告したい。

\section{* 東京工業大学工業化学科（杂京都目黒区大岡山）}

Tokyo Institute of Technology

\section{2. 実 験 方 法}

\section{2-1 試料の調製}

\section{2-1-1 砳摩試薬の調製}

DPA は市販の $\mathrm{H}_{3} \mathrm{PO}_{4}$ (比重約 1.7) を加熱脱水法に よって調製した。すなわち, $75 \% \mathrm{H}_{3} \mathrm{PO}_{4}$ 約 $500 \mathrm{~m} l$ を パイレックスビーカーにとり，ガスバーナ上で $250^{\circ} \mathrm{C}$ 付 近まで約 $1 \mathrm{hr}$ で加熱脱水させた後, 以後この温度付近 に保持して脱水を継続し，この間の時間の長短によって $\mathrm{P}_{2} \mathrm{O}_{5}$ 濃度を異にする DPA を得るようにした。本実験 に拈いて $\mathrm{P}_{2} \mathrm{O}_{5} 78 \%$ 付近の DPA を標準 DPA として 使用したが,その調製に必要な時間は約 $5 \mathrm{hr}$ であった。

有機試薬はいずれる市販の C.P. 級をそのまま使用し た。ただしアルコール類では燃料用メタノールも供試し た。

2-1-2 試片とその表面予備処理

本研摩浴の研摩能は一般の化学研摩浴々同様に被研摩 材の材質や顕微鏡的組織によって支配されるが，本実験 


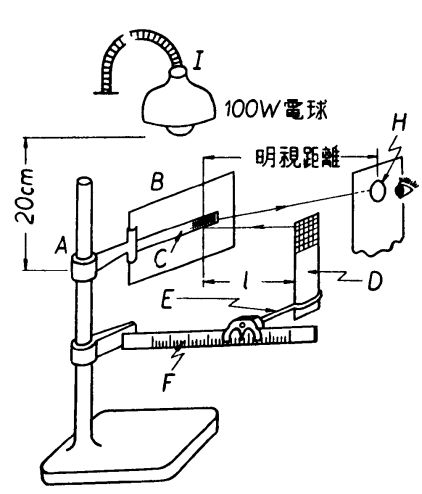

第 1 図平滑度の判定
では研摩されやす い素材で，その研 摩効果の優劣の判 定が比較的容易か つ明白な点を考虑 して, 線種 NG4W（公称 組成 C $0.6 \%$, Mn 0.47 $\%, \mathrm{Si} 0.27 \%, \mathrm{Cu}$ $0.13 \%$ )を用いた。 本素材の表面平滑 度は肉眼的にみて 均一とみなしうる ので，とくに予備研摩を行なわず後述の表面脱脂に意を 用いた。

なお，本浴の研摩作用の考察を目的として行なった溶 解試験用の試片には, 上記線材に近い炭素含有量をむつ 炭素鋼板を $20 \times 10 \times 1 \mathrm{~mm}$ のク形片に裁断したものを用 いた。表面はエメリー00番まで均一に研摩し, 脱脂, 水 洗後 $50^{\circ} \mathrm{C}$ の希塩酸液に $10 \mathrm{~min}$ 間浸セキ, 再で水洗, 風乾して仕上げた。

脱脂に関しては, 本混合系浴は従来の DPA-無機鉣酸 系研摩浴と異なり, その使用温度は約 $100^{\circ} \mathrm{C}$ 以下の比較 的低温度領域にあり, 表面の油脂性付着物が研摩浴の溶 解能に与える影響は.在来浴の場合より大きい。そこで脱 脂処理は入念に行ない, 脱脂液としては炭酸ナトリウム $100 \mathrm{~g} / l$, メタケイ酸ナトリウム $50 \mathrm{~g} / l$, カセイソーダ $150 \mathrm{~g} / l$ の $60^{\circ} \mathrm{C}$ 加温浴を用い，その中に試片を約 $30 \mathrm{~min}$ 浸セキ脱脂し, 水洗のさい均一水膜の形成を確認するよ うにした。

\section{2-2 研摩漫セキ操作}

所要温度まで加温した研摩浴約 $300 \mathrm{~m} l$ 中に, 前述の 前処理を施した線材試料 3 本を同時に垂直に浸セキし, 所要時閒䍩過後これらを取り出し, 暫時空気中に放置し て, 試料とその表面に付着した残存矿摩液との反応が終 了し発泡が認められなくなった後, 水洗, シアン化浴処 理, 再水洗を行ない, 最後に後述の研摩効果の判定を実 施した。研摩浴の加熱法, 浴中に引火性有機薬品を含む 点を考虑して，これを収容したパイレックスビーカーを 酎熱陶器中に満した廃脱水リン酸 (沸点約 $250^{\circ} \mathrm{C}$ ) の中 に沈め, 間接的に行なった。使用温度は $150^{\circ} \mathrm{C}$ 以下で特 に温度調節装置を用いてないが，砶摩浸セキ中浴の所定 温度は土2足の範囲に保たれた。一般に研摩効果は浴中 の鉄溶解生成物濃度に大きく依存するが, 本浴では後述 するよろに鉄溶解量は在来浴に比べ少ないため, この原 因による浴老化現象の発現は遅い。しかしその影響が認 められた場合（被研摩面上に着色性皮膜が生成する）に
は直ちに研摩浴は更新するよう留意した。

\section{2-3 研摩効果の評価}

\section{2-3-1 平滑度の判定}

研摩効果のうち, 平滑度の判定法としては, 試片の研 摩面を鏡とみなし，「標的」に対するその胦像能力によ って平滑度を判定する手段を採用した $30 \mathrm{~mm}$, 幅 $15 \mathrm{~mm}$ のケント紙に墨で幅 $1 \mathrm{~mm}$ の格子模 様を描いたものである。その操作は次の要領で行なっ た。

第 1 図で研摩した試料 Cは白地のつい立てBの直前に 㯰き, この研摩面に標的Dの格子模様が写るようにして 扣く。次につい立てのノゾキ穴Hから研摩面上のDに対

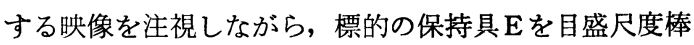
$\mathrm{F}$ 上に徐々に滑らして研摩面から遠さ㺭, その面上の映 像が消失した時の研摩面 C と標的 D との間の距離 $l$ を目

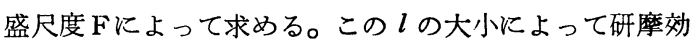
果の優劣を「光沢化優」「光沢化良」「ナシ地化」の 3 段 階に分けて判定した。lの大キサは照明電球 I のワット 数その位置などによって变化するが，一定条件の下で行 なえば相対的な判定に役立つ。たとえば本実験の場合は 次のよ5に定めた。 $l>25 \mathrm{~mm}$ の場合「光沢化優」, $15 \mathrm{~mm}$ $<l<25 \mathrm{~mm}$ の場合「光沢化良」, $l<15 \mathrm{~mm}$ の場合「ナ シ地化」。 通常上記の判定を同一試料について 3 回行な い, その值の平均値をむって $l$ の值として採用した。

\section{2-3-2 黒化度の判定}

化学研摩処理面は往々にして着色するが, 本浴のよう なリン酸系浴にあっては, 研摩条件のいかんによって黒 味を帯びた外観を呈することがある。このような黒化の 有無は, 吥摩効果の判定要素となるが, 前項の判定法て は評価ができない。すなわち, 黒色化した研摩面でも平 滑度が良好であれば「標的」の映像能力は大きく現われ るが, 化学研摩面としては不適である。本実験に拈いて は, 試片を研摩処理してのちシアン化浴中に約 $30 \mathrm{~min}$ 浸 セキし，表面に黒色皮膜があればこれを除去するように したが，なお視察によって黒色化の認められる試片はそ の程度を次のようにして判定した。

画用紙上に墨を使用して濃淡を異にする手製の標準明 度段階表を作り，このスケールを第 1 図のつい亡てBの 上にはり付け，スタンドAにとりつけてのち被検試料を それぞれの明度の位圆の上に㨁き，視察によってほぼ同 一の明かるさ (黒化度) をむっと思われる標準色を見出 し, その等級をもって便宜上その研摩面の明度とみなし た。そしてある等級注)以上の黒色化の認められる研摩面 試料は，その平滑度が良好です黒化試片と挸定した。

注）日本色彩研究所発行の「色と標準」(1951年)飞記載 の明度19亿ほほ相当する。 


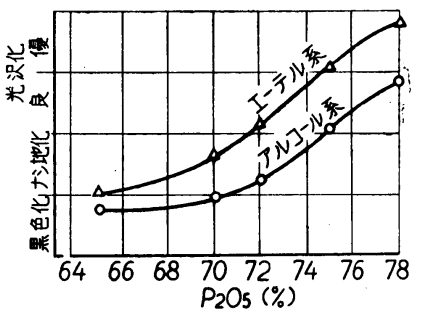

DPA 濃度と研摩効果との関係 第 2 図

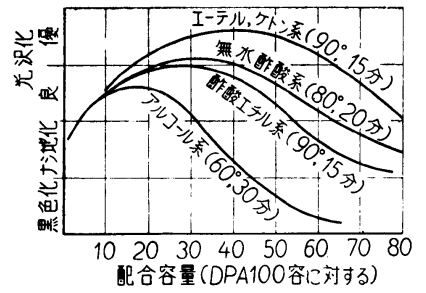

配合組成と研摩効果との関係 第 3 図

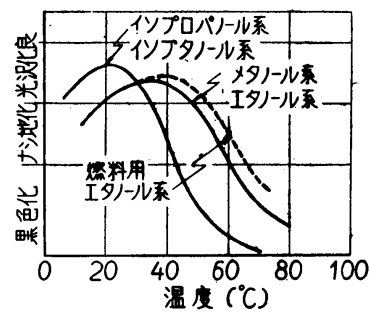

研摩温度と研摩効果との関係(アルコール系)

\section{3. 実 験 結 果}

\section{3-1 研糜効果の観窑}

3-1-1 濃度との関係

本混合系浴の DPA 成分について, その濃度が浴の研 摩能に与える影響をみる目的で, アルコール系拉よびェ ーテル系を対象に選び次のような実験を行なった。すな わち $\mathrm{P}_{2} \mathrm{O}_{5}$ 濃度がそれぞれ $65,70,72,75,78 \%$ の各 DPA 試料10容に対し，アルコール系ではメタノールを 2 容, エーテル系ではメチルェチルエーテルを 4 容配合した浴 (これらの浴構成は後述するようにそれぞれの系に打い て最良の研摩効果を期待しうる組成となっている）につ いて, 前述のような浸セキを行なってその研摩効果を観 察した。前述の方法で研摩面の平滑度を判定した結果を 第 2 図に示す。これをみると脱水度の進行した， $\mathrm{P}_{2} \mathrm{O}_{5}$ 濃度の大きいDPA を用いた混合系ほどその研摩能は良 好であることが認められる。従来 DPA 単独浴ないし無 機試薬との混合系に打いて使用される DPA の濃度は普 通 74〜75\% 付近であるが, 本実験の結果から有機試薬 との混合系浴ではさらに高脱水度の DPA の使用がのそ ましいこそがわかった。この事実はアルコール系やエー テル系の混合系浴の場合だけでなく, 他の有機試薬系に ついても観察された。そこで以下の実験では 78\% DPA を使用することにしたが，この濃度を選んだ理由は次の ようである。

(1) 高濃度の DPA を多量に得るためには, $75 \%$ $\mathrm{H}_{3} \mathrm{PO}_{4}$ を $250^{\circ} \mathrm{C}$ 以上の高温で長時間加熱脱水を行なう 必要があるが, 往々にし、てこの途中で白濁化現象を生ず るため, $78 \%$ 濃度以上の DPA の調製は実際上困難で あった。

(2) このようなきわめて高濃度の DPA で構成した混 合系浴を使用した場合，a）研摩面上に白色粘着性皮膜 が形成されやすく, 点食の発生を促す危険性がある。 b) 最適の使用条件は $100^{\circ} \mathrm{C}$ 以上であって, この種の混 合浴としては比較的高い操作温度が必要である, などの 研摩浴として好ましくない現象が現われてくる。以上の 理由で $78 \%$ 付近の $\mathrm{P}_{2} \mathrm{O}_{5}$ 濃度をもって一応本湿合系浴
を構成する DPA の最尰濃度とみなした。

\section{3-1-2 配合組成との関係}

有機試薬の配合量の多少が，その混合浴系の研摩能に 及ぼす影響を観察した結果を第 3 図に示す。横軸はDPA $\left(\mathrm{P}_{2} \mathrm{O}_{5} 78 \%\right) 100$ 容に対する 配合有機試薬の容量を目 盛ってある。これら各混合系浴を用いて研摩するさいの 浸セキ時間，温度は図中に付記してあるが，その值はほ ぼそれぞれの系に拈ける最適条件(後述)に選んである。 これから次の観察がなされた。1）研摩効果はエーテル 系浴, ケトン系浴に掠いて最すすぐれ，これに比してメ タノール系浴はあまり良好でない。2）特にメタノール 系浴（のみならず一般のアルコール系浴でも）では配合 の過剰はいちじるしく研摩面を黒色化する傾向が目立 ち，適正な配合量は最大 $20 \%$ 付近を限界とする。これ に対して, ェーテル系浴, ケトン系浴は $50 \%$ 付近で研 摩効果は良好であり，80\%付近まで配合可能であるが， それ以上は研摩効果を劣化させるようである。ただし， この場合でもアルコール系浴の場合のよ5に表面のいち じるしい黑色化現象は認められない。3）無水酢酸系 浴, 酢酸エチル系浴では $50 \%$ 付近屯で配合でき, 最適 組成は $30 \%$ 付近に認められたが, その研摩効果はエー テル系浴，ケトン系浴に劣る。ただし配合過剩の結果, 研摩面の黑色化をきたすことはない。

以上の実験結果から良好な研摩効果を与える.上記有機 試薬の最適配合量をDPA 100 容に対して次のように 定めた。

アルコール系浴 20 容, エーテル系浴およびヶトン系 浴 50 容, 無水有機酸系浴 40 容, 酢酸エチル系浴 30 容

\section{3-1-3 研摩温度}

研摩（浸セキ）温度の研摩効果に与える影響を観察し た。浴組成执よび研摩時間は前項に記した条件と同一で ある。

(a) アルコール系 第 4 図はアルコール系浴について 得られた結果であるが，これから本浴の研摩作用は低温 度域に打いて比較的良好であるが, 温度が高くなると研 摩面は黑色化の傾向が現われ始め, 研摩効果は急激に劣 化することがわかる。このような傾向はメタノール，ェ 


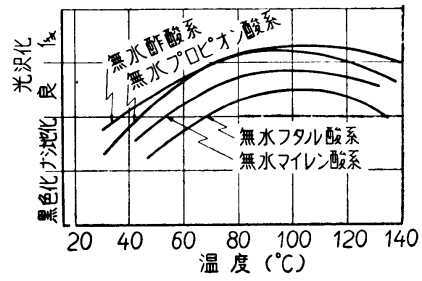

第 5 図研摩温度と研摩効果との 関係（無水有機酸系）

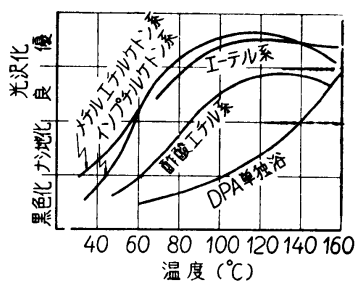

第 6 図研摩温度と研摩効果との 関係（ケトン系その他）

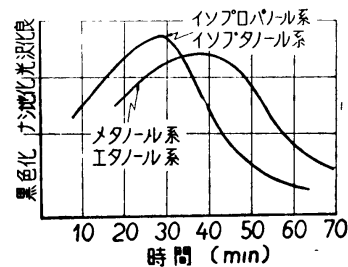

第7図 研摩時間と研摩効果との 関係（アルコール系）
タノールのような低級アルコールにくらベ，イソプロパ ノール，イソブタノールのような前者より高級なアルコ 一ルに括いてとくに顕著に認められ，前者においては約 $60^{\circ} \mathrm{C}$ 付近から，後者においては $40^{\circ} \mathrm{C}$ 付近からすでに見 出された。ただし $50^{\circ} \mathrm{C}$ 以下の低温度領域に括ける研摩 効果は後者の方が前者に比べやや良好であった。

なお，エタノール浴の場合において，然料用アルコー ルを用いても，試薬級に劣らず，むしろすぐれた研摩効 果が得られている点は実用的観点から注意された。また 表面に生成した黒色皮膜はシアン化浴処理によってある 程度の除去が可能であるが，この場合も高級アルコール 系で研摩した試片上の黒色皮膜は低級アルコール系のそ れにくらべ除去が困難であった。

(b) 無水有機酸系 無水酢酸系, 無水プロピオン酸系 無水マイレン酸系および無水フタル酸系の 4 種類の浴に ついて研摩効果に及ぼす温度の影響を観察した。これら 4 試薬のうち, 前 2 者は常温で液体であり, 前述の規定 量 $(40 \%)$ を配合して供試したが, 後の 2 試薬は固体で あって，その DPA に対する溶解度住は常温付近で小さ いため，約 1〜 5\%（重量）を配合して使用した。

実験結果を第 5 図に示す。この種の混合系浴では, 温 度の研摩効果に及ぼす影響はアルコール系の場合と明ら かに異なり, 温度上昇に伴 5 黒色化の現象は認められず むしろその研摩作用は $70^{\circ} \mathrm{C}$ 以上で良好であった。個々 の試薬についてみると，1）ともに脂肪族に属する無水 酢酸系浴と無水プロピオン酸系浴の研摩作用を比較する と, 両者にほとんど差異は認められない。ただ詳細に観 察すると, $60^{\circ} \mathrm{C}$ 付近以下の低温度では前者（低分子量の もの）が幾分まさるが， $90^{\circ} \mathrm{C}$ 以上の温度では後者の方が やや良好であった。2）しかるに，芳香族に属する無水 フタル酸系浴では, 研摩面上に白色ないし灰色の固着性 皮膜が形成されやすく，かつこの皮膜は水洗によっても 除去困難ですみやかに黒色化する傾向があり, 前記 2 試 薬と明らかに異なった挙動が注目された。

以上は,さきのアルコール系の場合と同じく, 同一の

注）DPAの脱水度や有機試薬自体の純度などによって この溶解度は影響されるようである。
無水有機酸系統においても, その試薬の種類によって, その配合浴の研摩作用に与える影響は必ずしも一様でな いことを示す事実と考えられる。

(c) ケトン系その他 メチルエチルケトン，イソブチ ルケトンの 2 ケトン系試薬, ならびにエーテルおよび酢 酸エチルの 4 試薬を配合した浴について行なった実験結 果を第 6 図に記す。この種の混合系浴は，いずれも前記 の無水有機酸系浴と同じく良好な研摩温度の範囲は80 $120^{\circ} \mathrm{C}$ にあり，アルュール系の場合に拈けるように温度 上帠に伴う黒色化現象は認められなかった。しかし， 1） $150^{\circ} \mathrm{C}$ 付近の高温度浴で使用した場合は,研摩面上に 白色皮膜が局部的に付着して均一な研摩作用を阻害する 結果をきたす。この皮膜は入念な水洗によって除去でき るが，その裏側の鉄素地にはわずかではあるが点食が発 生していることが顕微鏡で明らかに観察できた。2) 次 に, 同一の脂肪系のケトン試薬として, メチルエチルケ トン系とイソブチルケトン系の両者について, その研摩 作用を比較してみると，大差は認められないが，60 下の低温度領域では前者（低分子量のもの）の方がやや すぐれているようである。しかし，さらに高い温度領域 ではこの差はほとんど認められなくなる。以上の傾向は 前述の無水酢酸系と無水プロピオン酸系の場合とだいた い類似している。3）さらに，エーテル系浴の研摩作用 は, ケトン系浴と近似しており, 一方酢酸エチル系浴の 研摩作用は, ケトン, エーテル両浴にくらべ幾分劣るこ とが見出された。

第 6 図には DPA 単独浴を使用した場合も併記してあ るが，これを上述の有機試薬配合浴の場合と比較してみ ると，1） $100^{\circ} \mathrm{C}$ 以下の低温度領域においては， DPA 単独浴は研摩面を黒色化するが，有機試薬配合浴では一 般に（アルコール系のような場合を除いて）このおそれ がないこと。2） $150^{\circ} \mathrm{C}$ 付近の比較的高い温度に拈いて は, 両者の研摩効果は視察から大差は認められない。し かし顕微鏡で精査の結果では点食の発生が有機試薬配合 浴で処理した試片面には少ないのに反して, DPA 単独 浴で処理した試片面には多いことが注意された。

\section{3-1-4 研摩（浸セキ）時間}




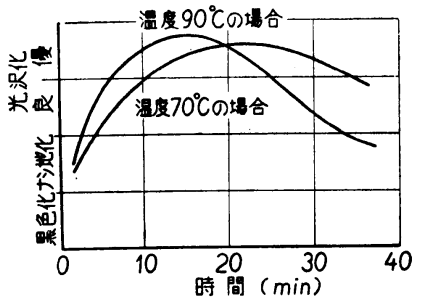

第 8 図研摩時間と研摩効果と の関係（イソブチルケ トン, 無水酢酸, エ一 テルの各系)

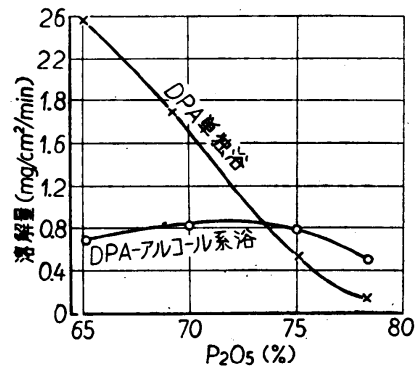

第 9 図 DPA 濃度と溶解量と の関係

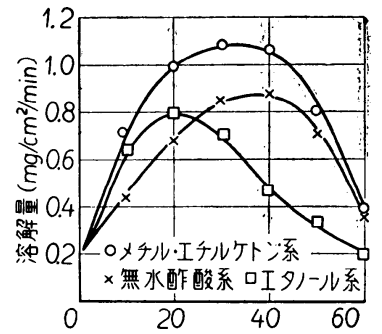

配合容量(DPA100 容に対する)

第10図 配合組成と溶解量との 関係

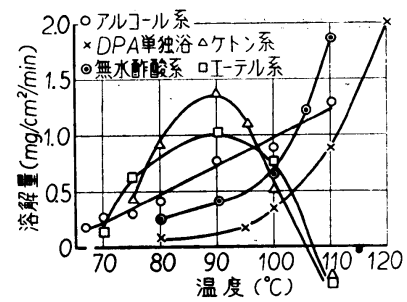

第11図研摩温度と溶解量との 関係

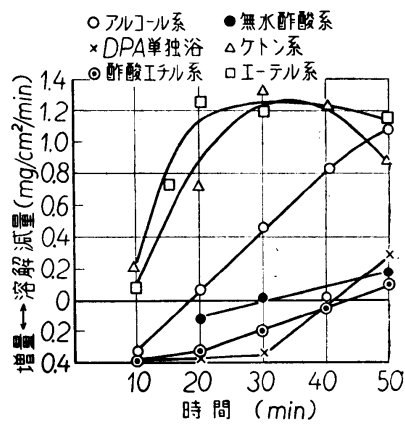

第12図研摩时間と溶解量との 関係

$\left(75^{\circ} \mathrm{C}\right.$ の場合)

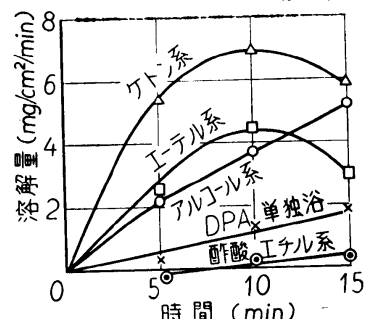

第13図 研摩時間と溶解量との 関係

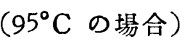

着性皮膜の付着が認められ，点食発生の 原因と沈る。また研摩温度の上昇は適正 研摩時間を短縮する。

他の有機試薬浴, たとえば無水プロピ オン酸, 無水フタル酸, 酢酸エチルなど の系の砸摩効果と時間の関係は上述の傾 向ときわめて類似しているので，その図 示は省略する。

\section{3-2 溶解昌の観察}

化学研摩現象は, 研摩浴中における試 片の溶解量と密接な相関性をもってい る。そこで本項では DPAに 前述した有 機試薬を配合した浴中における鉄溶解量 と浴組成，浴温度および浸セキ時間との 関係を観察した。

\section{3-2-1ＤPA 濃度との関係}

第 9 図は各種濃度の DPAを用いて, DPA 単独浴拈よび DPA-アルコール 混 合系浴 (10容：2 容) 中に拈ける鉄の溶 解量（浸セキ時間 $30 \mathrm{~min}$ ) を, 使用した DPA の $\mathrm{P}_{2} \mathrm{O}_{5}$ 濃度に対してプロットし たものである。これから DPA 単独浴中 の鉄溶解量は DPA 濃度の増加とともに 急激に減少するが，アルコールを配合し た混合浴においては大きな変化はなく， かえって75\%付近まではわずかであるが 溶解量が増す傾向が認められた。またこ の結果から，75\%以上の高濃度 DPA に アルコールを配合することによって，鉄 溶解能の活性化に寄与せしめうることが 明らかとなった。

\section{3-2-2 配合組成との関係}

有機試薬の配合量の多少がその混合浴中の鉄溶解量に 及ぼす影響を示す実験を第10図に掲げた。DPA に対し て 20〜 40\% の配合組成の付近に执いて，いずれも溶解 量の極大を示すピークが現われているが，エタノール系 ではそのピークの形がメチルエチルケトン系や無水酢酸 系にくらべて鋭くかつその位置は低い配合組成の側（原 点寄り）に片寄っている。このような傾向はェタノール 系の場合だけでなく，イソプロパノール系，イソブタノ ー・ル系の場合にも顕著に見出すことができた。このよう に溶解量と配合組成との間に認めることがでさたアルコ ール系浴の特性は, ケトン系浴にくらべこのアルコール 系浴では最適研摩効果を与兄る配合範囲が狭く, かつ小 さいという前述の観察結果に完全に対応している事実は 注目される。

3-2-3 研摩温度との関係 
温度と溶解量との関係を第11図に示す。これから，指 数関数的に急増する温度特性を示す DPA 単独浴有機試 薬を配合した場合, その種類によって混合浴中の鉄溶解 量の対温度推移にはかなり異なった傾向が現われること。 がわかる。すなわち，1）アルコール系では直線的に増 加する。2）ケトン系浴, エーテル系浴では $90^{\circ} \mathrm{C}$ 付近 に極大值が現われ， $110^{\circ} \mathrm{C}$ 以上では研摩浸セキによって 逆に重量増加の現象さえ見られる。3）無水酢酸系浴で は DPA 単独系と類似の指数関数的増加の傾向を示す。

これらの結果は，DPA に対する有機試薬の配合は， 浴自体の対金属溶解挙動に影響を与えることを明らかに 示している。しかしその影響される程度は配合される試 薬のいかんによって異なり, 無水酢酸系の場合は小さい が，アルコール系特にエーテル系やケトン系では大きい ことがわかる。エーテル系やヶトン系の高温度浴中に浸 セキされた試片の表面は，白色皮膜で強固に沶拉われる のが見られ，これが重量増加をきたす原因となってい る。これらの点については考察の項で再述する。

\section{3-2-4 研摩時間との関係}

混合浴中の溶解量と時間との関係を温度 $75^{\circ} \mathrm{C}, 95^{\circ} \mathrm{C}$ の2つの場合について観察した結果を第12,13図に示し てある。これから 1) アルコール系浴では值線的傾向を 示し，2）エーテル系浴，ヶトン系浴では浸セキ初期か ら盛んな溶解作用を示すが，経時的に飽和傾向ないし極 大型の推移をたどる。3）DPA 単独浴や無水酢酸系浴, 酢酸エチル系浴の溶解作用は緩慢で, $75^{\circ} \mathrm{C}$ 場合浸セキ 初期ではかえって重量増加の傾向さえ示している。これ らの経時的挙動が浴の研摩作用と密接な相関性をむつ事 实は後述する。

\section{4. 考}

察

\section{4-1 本混合浴の研摩作用}

化学研摩浴は, その中に浸セキされた金属表面の微視 的凸部を優先的に溶解せしめ, その結果表面の平滑化が 可能となるような機能が必要である。このため研摩浴が 具備しなければならない第一の重要な性質は, 盛んな対 金属溶解能であり，第二は柔軟な可溶性表面皮膜層を溶 解面上に形成させることのできる皮膜形成能であると考 えられている3)。この観点から，上に得られた実験結果 について以下考察を加えてみたい。

上述した研摩浴の溶解能と皮膜形成能に関しては, そ の浴中に浸セキされた鉄試片の溶解量の観察からだいた いの推定が得られることが期待される。そこで $3-2$ の 項でのベた溶解量と浴組成, 浴温度および試片の浸七キ 時間との関係を眺めてみると, 次に列挙する諸事実が注 目される。

（1）本混合浴が DPA 単独浴ないし DPA-無機鉱酸系
混合浴にくらべて特にすぐれている点は，100C以下の 低温度域に扣いて研摩が可能なことである。第11図をみ ると, $100^{\circ} \mathrm{C}$ 以下の温度域では本混合浴中の鉄溶解量は DPA 単独浴中のそれにくらべいずれも大きい值を示し ている。

（2）次に，本混合系研摩浴相互を比較すると，アルコ ール系浴では $70 \sim 60^{\circ} \mathrm{C}$ 以下の低温度域に拈いて, エー テル系浴, ケトン系浴では約 $70^{\circ} \mathrm{C}$ 以上の比較的高い温 度領域において研摩効果がすぐれているが，第11図をみ

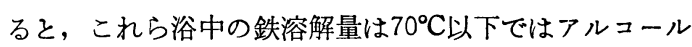
系浴の方が, $70^{\circ} \mathrm{C}$ 上ではトケン系浴やェーテル系浴の 方が大きい。(ただし，100C以上の高温度領域では再び 上述の関係は逆転しているが，この点はあとで触れる）

（3）本混合浴に併用する DPA 試薬は, 従来の単独浴 ないし無機試薬配合浴の場合にくらべ, さらに高濃度の DPA が適するが，第 9 図をみるとDPA-アルコール系 混合浴中の鉄溶解量が DPA 単独浴中のそれより大きく なるのは $\mathrm{P}_{2} \mathrm{O}_{5} 74 \%$ 以上の高濃度範囲である。

(4) 第10図に示した鉄溶解量の対組成曲線をみると, 20 40\%付近に極大值の存在が示されているが，それぞ れの有機試薬の最適配合組成もこのピーク付近にある。

これらの実験事実は, 研摩浴の機能すなわち研摩能を 構成する第一の重要な因子は強力な対金属溶解能である そいう筆者らのさきの推定を裏付けるものと考えられ る。

しかしながら次のような事実，1）本混合浴中の鉄溶 解量は DPA 単独浴中のそれにくらべて低温度領域にお。 いて遥かに大きい。しかし従来の DPA 単独浴を使用し て, その研摩能を発揮させるに必要な温度は $150^{\circ} \mathrm{C}$ 以上 であって, この場合の鉄溶解量に比べると, それは的 $1 / 2$ 以下であること。また，2）アルコール浴中の鉄溶解量 は前述したよ 5 に $70^{\circ} \mathrm{C}$ 以上ではケトン系浴, エーテル 系浴中のそれより小さいが, $100^{\circ} \mathrm{C}$ 以上の温度では再び 大きくなっている。それにもかかわらずその研摩能はヶ トン系浴やエーテル系浴のそれに及ばないこと，に注意 すれば金属溶解能は研摩浴の具備しなければならない必 要条件であるが，十分条件ではないことが知られる。す なわち前述の第二の要件である皮膜形成能をあわせて考 虑すべきである。

金属の溶解反応には必ず溶解抵抗をともならが，その だいたいの経時的挙動は溶解量の時間的推移を示す曲線 から観察できる。第12,13図をみると，この曲線は浴の 種類によって異なる傾向性を示し, DPA 単独浴無水酢 酸系浴およびアルコール系浴などではほぼ直線型であり したがって溶解抵抗もだいたい一定であると考兄られ る。しかるにケトン系浴, エーテル系浴では飽和型ない し極大型の外観を呈し, 経時的にすみやかに強力な溶解 
第 1 表 新浴 (D P A-有機試薬系) と在来浴 （D P A-無機試薬系）の比較

\begin{tabular}{|c|c|c|}
\hline & 在 来 浴 & 新 \\
\hline 浴構成法 & $\begin{array}{l}\mathrm{D} P \mathrm{PA}\left(\mathrm{P}_{2} \mathrm{O}_{5}{ }^{74} \sim 76\right. \\
\%) \mathrm{K} \mathrm{H}_{2} \mathrm{SO}_{4}, \mathrm{CrO}_{3} \\
\text { などの無機鉣酸添加 } \\
\text { (10\% 以下下) }\end{array}$ & 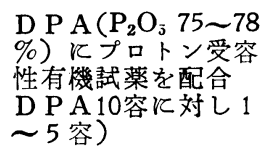 \\
\hline 被研摩材 & $\begin{array}{l}\text { C含有量, 金相組織 } \\
\text { 飞依存 }\end{array}$ & 右に同じ \\
\hline 前 処 理 & $\begin{array}{l}\text { 撖密な脱脂, 酸洗イ } \\
\text { を必要とせす }\end{array}$ & 脱脂を可とす \\
\hline 研摩温度 & $150 \sim 200^{\circ} \mathrm{C}$ & $40 \sim 100^{\circ} \mathrm{C}$ \\
\hline 研摩時間 & 数秒〜数分 & 数分〜数十分 \\
\hline $\begin{array}{l}\text { 㭝質 の } \\
\text { 溶解損失 }\end{array}$ & 大 (約 $\left.2 \mathrm{~g} / \mathrm{M}^{2} / \mathrm{min}\right)$ & 在来浴の1/2以下 \\
\hline $\begin{array}{l}\text { 水素ゼイ } \\
\text { 性の危険 } \\
\text { 性 }\end{array}$ & 大 & 小 \\
\hline $\begin{array}{l}\text { 研摩面の } \\
\text { 安定 性 }\end{array}$ & $\begin{array}{l}\text { 比較的小, 表面黒色 } \\
\text { 化の傾向あり }\end{array}$ & 安定性大なる るのあ \\
\hline $\begin{array}{l}\text { シアン化 } \\
\text { 浴の後处 } \\
\text { 理 }\end{array}$ & 効果あり & $\begin{array}{l}\text { アルコール系で効果 } \\
\text { 多し }\end{array}$ \\
\hline 浴 管 理 & $\begin{array}{l}\text { 空気中放置により吸 } \\
\text { 湿, 研摩能劣化 }\end{array}$ & 右の傾向は少し \\
\hline 浴 寿 命 & $\begin{array}{l}\text { 溶解鉄の蓄積による } \\
\text { 老化の傾向大, } \\
\mathrm{H}_{2} \mathrm{SO}_{4} \text { 添加により更 } \\
\text { 生 }\end{array}$ & $\begin{array}{l}\text { 溶解鉄の蓄積少ない } \\
\text { ため老化速度小, 有 } \\
\text { 機試薬の補充で更生 } \\
\text { 可能 }\end{array}$ \\
\hline 研摩操作 & $\begin{array}{l}\text { 比較的高温のため注 } \\
\text { 意を要す }\end{array}$ & $\begin{array}{l}100^{\circ} \mathrm{C} \text { 以下で作業容 } \\
\text { 易 }\end{array}$ \\
\hline 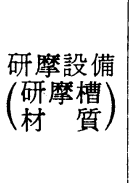 & $\begin{array}{l}\text { 耐熱,耐 D P A ( D P } \\
\text { A } 150^{\circ} \mathrm{C} \text { 以で種 } \\
\text { 々の金属材料に対し } \\
\text { てきわめて腐食性) } \\
\text { の特殊研摩槽污よび } \\
\text { 治具が必要 }\end{array}$ & 右の必要性少し \\
\hline
\end{tabular}

抵抗が溶解面上に形成されることを示している。そして この種の溶解挙動を示寸場合では, 長時間の鉄試片浸七 キによって研摩面上に白色ないし兏色の水洗では除去困 難な固着性皮膜の形成が認められ，これが強力な溶解抵 抗として作用していることがわかる。一方浴の研摩能と の関連性についてみると，1）直線型のアルコール系浴 などにくらべ，飽和ないし極大型を示すェーテル系浴， ケトン系浴の方がすぐれた研摩能をもつこと。2）後者 の混合浴で研摩するさい, 研摩現象の発現は溶解量一時 間曲線の飽和部分ないし極大值を示す付近で 認められ る。このような事実は, 浴の研摩能は溶解面上飞適正な溶 解抵抗が存在してはじめて発揮されることを意味し, 前
述した多孔性柔軟で可溶性の皮膜形成能が, 溶解能につ いで研摩浴の必要な機能であることを示するのであろう 同一の有機試薬系浴です，たとえば，アルコール系で はメタノール，エタノールとイソブタノール，イソプロ パノールの間に，ケトン系ではメチルエチルケトンとイ ソブチルケトンの間に, 無水有機酸系では酶酸, プロピ オン酸, フタル酸などの無水酸の間に, それぞれの研摩 効果ならびに研摩条件（温度, 時間) について差異が見 出される理由は, この溶解能, 皮膜形成能の違いによる ものと理解される。るっとも同一系統の試薬の問に拈け る炭素数の差（分子量の大小）の研摩効果に及ぼす影響 は, 今回試みた試薬類の範囲内ではとくに著しいとは考 えられないが（たとえばケトン類のメチルエチルケトン 系々.イソブチルケトン系の場合, あるいは同一の無水有 機酸類でも無水酷酸系と無水プロピオン酸系のようなと もに鎖状構造で炭素数のみ異なる試薬の場合），構造的 にかなり大きな差異のある場合，たとえば無水フタル酸 系のようなベンゼン核をるつ無水酸浴と上記の脂肪族系 の無水酸浴の間にはかなり明らかな研摩効果の差異, す なわち無水フタル酸浴では固着性皮膜状物質の形成によ る研摩面の著しい劣化作用が認められている。したがっ てこの場合は両者に批ける液体構造上の違いが皮膜形成 能の面に支配的に現われ，その結果研摩効果の差異とし て大きく影響を及ぼしているように想像される。

以上化学研摩浴の要件として盛んな溶解能と適正な皮 膜形成能の二者を想定して, 本混合系研摩浴中の鉄溶解 量の対時間, 対温度などの諸挙動を観察すれば, これと 研摩効果との関連性が首肯できること, そして, これか ら DPA にある種の有機試薬を配合することによって $100^{\circ} \mathrm{C}$ 以下の低温度領域にお牧溶解能の活性化々同時 に皮膜形成能の強化が可能となる事実を推定した。

筆者らが別に行なった本混合系浴に関する吸収スペク トルの測定実験からプ゚ロン受容性の 有 機試薬4) DPA に配合すれば, 両者の間に 付加的分子化合物を生 じやすいこと，またこのものは比較的不安定で二次的に 解離ないし分解してプロトン親和力を異にするイオン種 を一部生成することが推定されている5゙。したがって上 述の事実は，プロトン酸としての DPA にプロトン受容 性の有機試薬が配合された結果本混合系浴中に付加化合 物, ならびにその二次的生成物である比較的プロトン親 和力の小さなイオン種の形成が促進され, これらが浴の 溶解能の活性化と皮膜形成能の強化飞寄与寸ると考兄ら れるが，その詳細は別報に譲りたい。

\section{4-2 本研摩浴の特色}

以上今回試みた有機試薬の種類は多くないが，一応こ の種の DPA-有機試薬系混合浴を使用することによって 従来 $150^{\circ} \mathrm{C}$ 以上の高い温度を必要とした研摩温度条件を 
$100^{\circ} \mathrm{C}$ 以下に引下げうる可能性が示された。今後本浴が 鉄鋼に刘する低温化学研摩浴として活用されることを期 待したい。しかし本浴の実用化には，使用する試薬類が いずれも比較的高価であり注)，また引火性の危険薬品を 含むことから, 本浴の経済的生産, 管理や安全操作沉ど 研究すべき多くの問題点を含むことを最後に指摘してお きたいと思う。

なお，本法を実用化した場合，従来の DPA一無機試薬 系と比較して特色と思われる諸点を一覧表をもって示す と第 1 表のようになる。

\section{5. 要旨}

DPA に二三の有機試薬を配合した 混合系浴の鉄に対 する化学研摩作用に関する知見を得る目的で, 本浴中に 浸セキした鋼の研摩状態ならびにその溶解量と浴組成, 浴温度, 浸セキ時間との関係を観察した。

(1) 研摩浴は $\mathrm{P}_{2} \mathrm{O}_{5} 75 \%$ 以上の DPA（普通 $\mathrm{P}_{2} \mathrm{O}_{5} 78 \%$ 程度) 10 容に対して，アルコール，エーテル，ケトン，

注）アルコール系混合, $99 \%$ 浴の場合純度の試薬級の代 わりに然料用メタノールの使用が可能でありむしろ より良好な結果を得ていることは注目されてょいで あろ5。今後は安価な回収アルコールなどの利用が 陚みられる必要があるう。

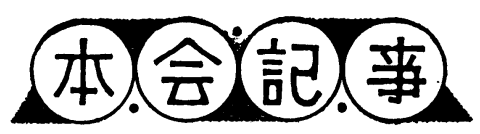

\section{8 月分事業（会議 3, 催物 3)}

9 日 10周年記念ブラウント氏特別講演会(山ロホール)

12日 第96回理事会ならびそ筑田理事祝賀会（治作）

19日 10周年記念松本講演会打合会（R.と５き 万)

22日 亜鉛メタリコン JIS 委員会（R・とうきょう）

23日メッキ部会幹事会（ニュー・トウキョウ）

26日 金属塗装研究会（R.とうきょ 5 )

10周年記念ブラウント氏特別講演会 講演「アメリカ に括けるクロムメッキの現状」，「アメリカに打ける廃夜
無水有機酸など 1 〜容を配合した浴組成が有効であっ た。

(2) 上.記混合系浴は在来の DPA-無機試薬系混合浴に くらべ，一般にその研摩効果がすぐれているばかりでな く, 使用温度は $60 \sim 100^{\circ} \mathrm{C}$ の低温度領域にあること, ま た材質の溶解損失は従来法の1/2以下であることなどの特 長をもつ。ただしその研摩時間はやや長く数十分程度を 必要とする。

(3) この種有機試薬配合の効果は, 浴の溶解能の活性 化と皮膜形成能の強化の観点から理解することができる 終りに，本研究に対し終始ご指導ごべんたつを賜った 本学教授向正夫博士に厚くお礼申上げる。

(1959年6月, 本協会第19回講演大会において発表)

(1960-7-18 受理)

\section{文献}

（1）佐治, 向, 電化誌, 22, 158 (1954)

(2) J.Hérenguel, J.Boghen, Reve du Metallurgie, 50, 317 (1953)

（3）佐治, 向, 電化誌, 22, 296 (1954)

(4) R.S.Mulliken, J.A.C.S. 74, 811 (1952)

（5）佐治, 大野, 向, 学協会連合講演会 (昭34.11) 飞て 発表

処理について」, 映画「アメリカに扣ける自動研摩」, 参 会者 150 名。

第96回理事会 事業, 会計報告, 入退会者承認。ブラ ウント氏特別講演会を10周年事業とする。記念講演会に ついては, 八幡・山形の進行状況報告。名古屋は準備委 員長飞浅田幸作氏を委嘱, 時期は11月。大阪は11月17日 とし支部創立記念を兼ねる。オートスライドを予備費で 購入する。アカデミ一委員会第 1 期委員として下記 12 氏 を委嘱。(委員長) 麻田宏 (委員) 秋田武夫, 石田武男, 上田重朋, 島岡五朗, 多賀谷正義, 徳永惊, 中山孝廉, 久松敬弘, 松永正久, 山口文之助, 吉田忠。大塚賞は論 文賞とし編集委員会にて規定を作成する。委員長として 筑田理事を委嘱した。10周年記念号の後援会社あて寄贈 部数討議。他団体からの各種賞の推薦については会誌に て募集を行ない推萀委員会を設ける。

\section{日本機械学会賞昭和 35 年度募集}

応募対象 機械工学, 工業に関する論文括よび製品（論文は原則として昭和34年11月以降, 35年9月末日ま でに発行された刊行物に発表されたるの, 製品は最近に颃いて完成したもの)

表彰賞金 1 件 50000円（時期昭和36年 4 月）

申込方法 適当なるのは本協会にて推薦いたしますから希望者は本協会に招問合わせ下さい。

（本協会の推萀締切日. 10 月15日） 